\title{
Comparison of functional electrical stimulation associated with kinesiotherapy and kinesiotherapy alone in patients with hemiparesis during the subacute phase of ischemic cerebrovascular accident
}

Comparação da estimulação elétrica funcional associada à cinesioterapia com a cinesioterapia isolada em pacientes com hemiparesia na fase subaguda por acidente vascular cerebral isquêmico

Paulo Cesar Modesto', Fernando Campos Gomes Pinto²

\begin{abstract}
Objective: To compare the functional electrical stimulation associated with functional kinesiotherapy alone in patients after ischemic cerebrovascular accident. Methods: The study included 20 patients who were divided into two groups: Group I (Gl): functional electrical stimulation plus functional kinesiotherapy and Group II (GII): functional kinesiotherapy. We evaluated active and passive range of motion, in knee flexion and extension muscle strength, activities of daily living and quality of life. The evaluations were conducted in the pretreatment period, after 10 sessions and after 20 physical therapy sessions. Results: There was a significant improvement in all variables studied for both groups. However, significant improvements for the sub-items functional capacity and social aspects were seen only in the patients treated with associated functional electrical stimulation and kinesiotherapy. Conclusion: Although both groups of patients improved with the treatment, the association of functional electrical stimulation and kinesiotherapy showed superiority in two quality of life items, in the sub-items functional capacity and social aspects.
\end{abstract}

Key words: electric stimulation, stroke, paresis, physiotherapy.

RESUMO

Objetivo: Comparar a estimulação elétrica funcional associada à cinesioterapia com a cinesioterapia funcional isolada no membro inferior de pacientes em fase subaguda após acidente vascular cerebral isquêmico. Método: Participaram do estudo 20 pacientes divididos em 2 grupos: Grupo I (GI): eletroestimulação funcional mais cinesioterapia funcional e Grupo II (GII): cinesioterapia funcional. Foram avaliadas as amplitudes de movimento ativo e de movimento passivo em flexão e extensão do joelho, a força muscular, as atividades da vida diária e a qualidade de vida. As avaliações foram realizadas nos períodos pré-tratamento, após 10 e após 20 sessões de fisioterapia. Resultados: Houve melhora significativa em todas as variáveis estudadas para ambos os grupos. Contudo, melhorias significativas para os subitens capacidade funcional e aspectos sociais foram vistos apenas nos pacientes tratados com a estimulação elétrica funcional associada à cinesioterapia. Conclusão: Os dois grupos de pacientes melhoraram com o tratamento, mas a associação da estimulação elétrica funcional à cinesioterapia mostrou superioridade nos subitens capacidade funcional e aspectos sociais da qualidade de vida.

Palavras-Chave: estimulação elétrica, acidente vascular cerebral, paresia, fisioterapia.

The cerebral vascular accidents (CVA) are divided, according to their anatomical and pathological features, into subarachnoid and intraparenchymatous hemorrhages; and as ischemic (ICVA), caused by primary vascular disease, thrombosis or embolism and hemorrhagic (HCVA); divided, respectively ${ }^{1,2}$. Approximately $75 \%$ of CVA are ischemic and $25 \%$ are hemorrhagic ${ }^{2}$.

The acute stage of the disease is characterized by a state of flaccidity, areflexia, hemiplegia, hemi-anesthesia and

${ }_{1}^{1}$ Physical therapist, Master's Degree Student at Hospital do Servidor Público Estadual (IAMSPE-SP), São Paulo SP, Brazil;

${ }^{2}$ Physician, Neurosurgeon, Doctor of Neurosurgery at Universidade de São Paulo (USP); Post-graduate Advisor of IAMSPE-SP, São Paulo SP, Brazil. Correspondence: Paulo Cesar Modesto; Rua Corcovado 134 / bloco 54 / apto 28; 05038-040 São Paulo SP - Brasil; E-mail: pa.modesto@uol.com.br Conflict of interest: There is no conflict of interest to declare.

Received 22 August 2012; Received in final form 11 October 2012; Accepted 18 October 2012. 
cognitive alterations, which are the result of cerebral hypoxia and in accordance with the location of the lesion. The duration of this stage is usually brief and may finish in approximately 15 to 30 days, when the clinical course is modified and the individual then goes to a subacute stage, which last 1-3 months and can reach up to 6 months $^{3-6}$. In most cases, the return of function occurs spontaneously in one to three months after the CVA, reaching a plateau from six months to one year after the injury, although some patients exhibit substantial recovery at the later stages ${ }^{7-9}$.

Functional electrical stimulation (FES) is a resource used by physical therapy that enables the transmission of electrical signals to the muscles, facilitating movement ${ }^{10,11}$. It consists of functional electrical stimulation of a muscle deprived of normal control to produce a functionally useful contraction. This stimulation depolarizes the motor nerve, producing a synchronous response in all motor units of the stimulated muscle, improving throphism ${ }^{11}$. Its mechanism of action is closely linked to the facilitation of physiological mechanisms of striated muscle (muscle contraction), allowing selective and repetitive afferent input to the CNS, activating not only the local muscles, but also reflex mechanisms that are necessary for reorganization of the motor activity ${ }^{10,11}$.

The present study aimed to compare the FES associated with functional kinesiotherapy (FK) and functional kinesiotherapy alone in patients with sequelae of ICVA with hemiparesis in the subacute phase.

\section{METHODS}

The study included 20 patients of both genders with hemiparesis in the subacute phase after an ICVA. The sample consisted of 11 female and 9 male patients, with a mean age in Group I(GI) of 66.70 and 66.90 years in Group II (GII). The project was approved by the Committee of Ethics in Research of the Hospital do Servidor Público Estadual, São Paulo SP, Brazil, and the free and informed consent form was signed by all patients.

\section{Inclusion criteria}

Adult literate patients of both genders, aged 18 years and older, who were treated between July 2011 and January 2012 with ischemic CVA in the middle cerebral artery territory, with clinical and imaging diagnosis and within 90 days since the onset of the condition, with no structural deformities were included in the study.

\section{Exclusion criteria}

Patients with pacemakers, vascular alterations and sensitivity impairment in hemiparetic lower limb were excluded.

\section{Matching}

Study patients, whose score was lower than 85 in the initial Barthel Index (pretreatment assessment) were selected for the comparative analysis between the groups (study and control) to allow comparison of health-related quality of life (QOL) results from the patient's perspective and the performance of activities of daily life assessed by physical therapists in patients treated with FES+FK (GI) and patients treated with FK alone (GII).

\section{Evaluations}

\section{Muscle strength (MS) assessed by Daniels numerical} grading system ${ }^{12}$.

Barthel index (BI) is a scale that assesses functional capacity in activities of daily living and the degree of dependence from the perspective of the examiner.

\section{Quality of Life Questionnaire-SF-36.}

Joint range of motion ( $\mathrm{ROM})$ : joint range of motion (ROM) assessment was performed using a goniometer for the assessment of posterior and anterior ROM of the hemiparetic lower limb in knee extension and flexion. The patient remained supine and the lower limp (LL) was unclothed.

\section{Intervention}

The physical therapy intervention program for the groups (GI and GII) consisted of 20 physical therapy sessions twice a week in consecutive weeks, with 60-minute sessions for groups GI and GII, administered by the first author only.

\section{First phase}

Use of FES current; the electrodes were fixed on the thigh of the hemiparetic leg in the quadriceps muscle group (consisting of the rectus femoris, vastus lateralis/vastus medialis/vastus intermedius, knee joint), which promotes contractions in muscles deprived of nervous control.

We used the following stimulation parameters: frequency (F) of 30 to $100 \mathrm{~Hz}^{13,14}$; pulse width $(\mathrm{T})=250$ microseconds $^{13-15}$, cycle $\mathrm{ON} / \mathrm{OFF}=1 / 2$ (7 seconds of contraction/14 seconds of relaxation); the intensity was the minimum possible to produce an effective and uniform muscle contraction, respecting the voluntary thresholds ${ }^{16-19}$, as high intensities cause muscle fatigue ${ }^{18}$. Each FES session lasted 30 minutes.

\section{Second phase}

FK (therapeutic exercises directed at activities of daily living - ADLs), therapeutic exercises with entertaining features that encourage interpersonal relationship.

The FK that was administered is based on the guidelines of the American Physical Therapy Association. The summary of the exercises and their therapeutic goals are showed in Table $1^{20}$.

\section{Statistical analysis}

To compare the variables by group and assessment, we used two-way analysis of variance (ANOVA), with significance level set at 5\%. If a difference was detected, Tukey's multiple comparisons test was used. The variables were 
displayed as figures. These were distributed in order to demonstrate the evolution of patients from GI and GII, in the pretreatment period, after 10 sessions and at the end of 20 physical therapy sessions, verifying whether there was a difference between the evaluation periods, between the groups and for the interaction.

\section{RESULTS}

General distribution of patients in Groups I and II according to age and time since injury, are shown in Table 2.

There were no significant differences between groups regarding age and time since injury.

Table 3 shows gender, affected hemisphere and comorbidities. There were no significant differences between the groups regarding the parameters of the table.

\section{Quality of life: SF-36}

The SF-36 scale is subdivided into eight domains, namely: functional capacity, physical aspect limitation, pain, general health status, vitality, social aspects, emotional aspect limitation, and mental health.

\section{Functional capacity}

The mean score in the study group ranged from 62.80 (pre) to 69.03 (10 sessions) and 76.02 points (20 sessions) and in the control group, it ranged from 61.85 (pre) to 64.63 points (10 sessions) and 67.42 (20 sessions). The GI group showed significant improvement after the sessions, compared to GII ( $p=0.004)$ and at the time effect $(p<0.001)$ (Fig 1). We have the following hierarchy as a result: $($ Pre $)<(10$ sessions $)=(20$ sessions $)$ for both groups.

Table 4 shows the means and standard deviations of functional capacity.

Fig 1 shows the confidence intervals for each combination of group and time of assessment of the functional capacity sub-item for both groups.

\section{Social aspects}

The mean in the study group ranged from 66.20 to 66.30 (10 sessions) and remained at 66.30 (20 sessions), and in the control group, it ranged from 63.90 points (pre) to 64.60 (10 sessions) and remained at 64.60 (20 sessions). We observed a significant difference for both groups $(\mathrm{p}=0.034)$ and at the time

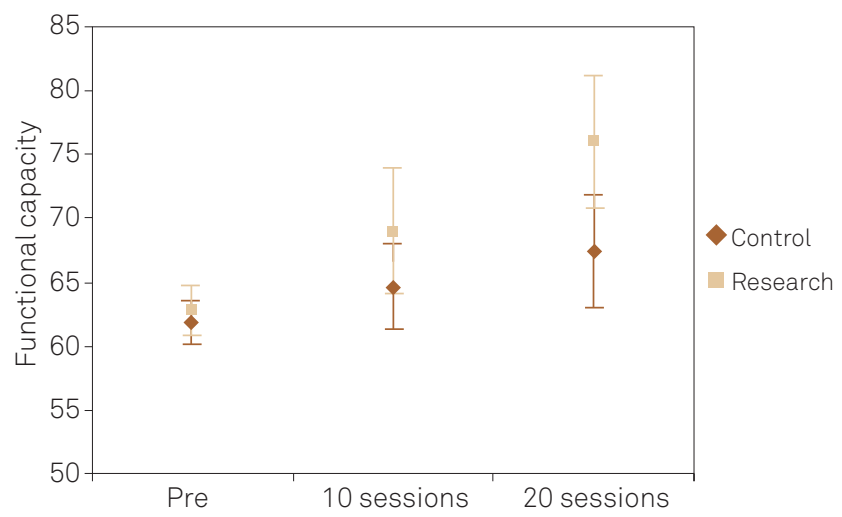

Fig 1. Confidence intervals for each combination of group and moment of assessment of the functional capacity sub-item for both groups.

Table 2. Age and time of lesion. General distribution of patients in Groups I and II, according to age and time of lesion.

\begin{tabular}{lccc} 
& $\begin{array}{c}\text { Study group G1 } \\
\text { Mean (SD) }\end{array}$ & $\begin{array}{c}\text { Control group G2 } \\
\text { Mean (SD) }\end{array}$ & t-test (p-value) \\
\hline $\begin{array}{l}\text { Age (years) } \\
\text { Time of }\end{array}$ & $66.70(8.54)$ & $66.90(12.32)$ & 0.967 \\
lesion (days) & $32.70(15.69)$ & $38.80(13.69)$ & 0.367 \\
\hline
\end{tabular}

SD: standard deviation.

Table 3. Gender, affected hemisphere and comorbidities. General distribution of patients in Groups I and II according to gender, affected hemisphere, hypertensives, diabetics, smokers and alcohol consumers demonstrated in \%.

\begin{tabular}{lccc} 
& $\begin{array}{c}\text { Study } \\
\text { group G1 }\end{array}$ & $\begin{array}{c}\text { Control } \\
\text { group G2 }\end{array}$ & $\begin{array}{c}\text { Fisher's test } \\
\text { (p-value) }\end{array}$ \\
\hline Female & $(5) 50 \%$ & (6) $60 \%$ & 1.000 \\
Male & $(5) 50 \%$ & (4) $40 \%$ & \\
$\begin{array}{l}\text { Right hemiparesis } \\
\text { Left hemiparesis }\end{array}$ & $(0) 0 \%$ & (4) $40 \%$ & 0.087 \\
$\begin{array}{l}\text { Systemic arterial } \\
\text { hypertension-Systemic }\end{array}$ & $(5) 50 \%$ & (8) $80 \%$ & 0.350 \\
$\begin{array}{l}\text { Arterial Hypertension } \\
\text { Diabetes mellitus }\end{array}$ & $(1) 10 \%$ & (5) $50 \%$ & 0.070 \\
$\begin{array}{l}\text { Smoking } \\
\text { Alcohol consumption }\end{array}$ & $(40) 40 \%$ & (3) $30 \%$ & 1.000 \\
\hline
\end{tabular}

Table 1. Functional kinesiotherapy. Physical exercises for lower limbs with therapeutic objective for orthostatic position.

\begin{tabular}{ll} 
Physical exercises & \multicolumn{1}{c}{ Therapeutic objectives } \\
\hline $\begin{array}{l}\text { Passive mobilization, active assisted or active free exercises, of } \\
\text { small and large joints of the axial and appendicular skeleton }\end{array}$ & $\begin{array}{l}\text { Maintain or restore normal joint flexibility and prevent clinical } \\
\text { complications arising from motor skill reduction }\end{array}$ \\
$\begin{array}{l}\text { Passive, active assisted, free, and resisted exercises of excursion, } \\
\text { stretching and muscle relaxation }\end{array}$ & $\begin{array}{l}\text { Maintain or restore the viscoelastic properties of muscle fibers, } \\
\text { preventing muscle shortening, as well as stimulating ideal tissue } \\
\text { Exercises that stimulate postural control, balance reactions and }\end{array}$ \\
$\begin{array}{l}\text { reactions of protection on stable and unstable surfaces in different } \\
\text { postures (lying, sitting, on all fours, kneeling, half-kneeling, }\end{array}$ & Stimulate the development of strategies to maintain balance and \\
standing, one-leg support) & body protection, adjusting the posture \\
$\begin{array}{l}\text { Exercises for aerobic capacity conditioning using functional } \\
\text { activities (rolling, sitting, standing and walking), monitor blood } \\
\text { pressure and heart rate }\end{array}$ & $\begin{array}{l}\text { Improve cardiorespiratory fitness, preventing cardiovascular } \\
\text { diseases and collaborating in the treatment of hypertension }\end{array}$
\end{tabular}


effect ( $\mathrm{p}=0.019)$ (Fig 2). We have the following hierarchy as result: $($ Pre $)<(10$ sessions $)=(20$ sessions $)$ for both groups, but the study group had higher responses at the three moments.

Table 5 shows the means and standard deviations of social aspects.

Fig 2 shows the confidence intervals for each combination of group and time of assessment of the sub-item social aspects for both groups.

Regarding other domains of the SF-36, and other items assessed, there was no significant difference from a statistical viewpoint.

\section{DISCUSSION}

The functional electrical stimulation was well tolerated by all study patients, respecting their tolerance threshold.

Although some hemiparetic patients with ischemic CVA may show spontaneous improvement, best results occur when patients are treated with physical therapy ${ }^{21,22}$.

Table 4. Means and standard deviations: functional capacity.

\begin{tabular}{|c|c|c|c|c|}
\hline \multirow[t]{2}{*}{ Group } & & Pre & 10 sessions & 20 sessions \\
\hline & Mean & 61.85 & 64.63 & 67.42 \\
\hline \multirow[t]{3}{*}{ Control } & SD & 2.61 & 5.04 & 6.81 \\
\hline & $\mathrm{n}$ & 10 & 10 & 10 \\
\hline & Mean & 62.80 & 69.03 & 76.02 \\
\hline \multirow[t]{2}{*}{ Study } & SD & 3.01 & 7.59 & 7.98 \\
\hline & $\mathrm{n}$ & 10 & 10 & 10 \\
\hline \multicolumn{5}{|c|}{ ANOVA Table } \\
\hline \multicolumn{4}{|l|}{ Effect } & $p$-value \\
\hline \multicolumn{4}{|c|}{ Group (Control x Study) } & $0.004^{*}$ \\
\hline \multicolumn{4}{|c|}{ Moment (pre, 10 sessions, 20 sessions) } & $<0.001 *$ \\
\hline \multicolumn{4}{|c|}{ Group x Moment (interaction) } & 0.132 \\
\hline \multicolumn{5}{|c|}{ Tukey's multiple comparisons for Moment effect } \\
\hline & & Pre & 10 sessions & 20 sessions \\
\hline \multicolumn{3}{|l|}{ Pre } & $0.050 *$ & $<0.001^{\star}$ \\
\hline \multicolumn{2}{|c|}{10 sessions } & $0.050 *$ & & 0.132 \\
\hline \multicolumn{2}{|c|}{20 sessions } & $<0.001 *$ & 0.132 & \\
\hline
\end{tabular}

SD: standard deviation; * statistically significant.

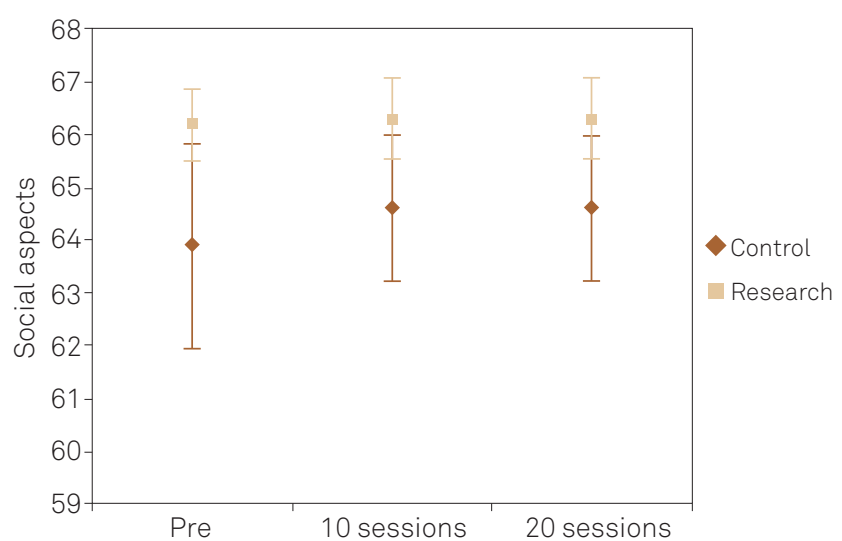

Fig 2. Confidence intervals for each combination of group and moment of assessment of the social aspects sub-item for both groups.
The element that made up the study intervention and promoted satisfactory results was the fact that the beginning of the program did not exceed 40 days since the CVA onset. It has been suggested that treatment started as soon as possible is a factor to achieve more satisfactory results ${ }^{22}$. Some authors have inferred that the early start of therapy seems to be more important for patient evolution than the duration of the program ${ }^{23}$.

Regarding muscle strength, the study showed a significant increase in strength after the treatment period, in flexion and knee extension for both groups, with no difference between them. The improved strength in GI (FES+FK) is consistent with the studies of Kesar et al. ${ }^{24}$, which determined that the FES facilitates recovery of muscle strength, increasing isometric strength of knee extensors and flexors in individuals with hemiparesis due to CVA.

Traditionally, epidemiological studies with a population of CVA patients are focused on mortality and its occurrence, but not on quality of life of these patients ${ }^{25}$, considering that the dysfunctions and disadvantages in this regard are significant for CVA patients ${ }^{26}$.

Although the quality of life for CVA patients is clearly influenced by multiple factors, functional independence is one of the most important factors ${ }^{27}$.

In this study, regarding quality of life, the results demonstrated significant improvement in the group that underwent treatment with FES+kinesiotherapy, in the functional capacity and social aspects domains, demonstrating that the combination of the two techniques was more beneficial than kinesiotherapy alone. For the pain, vitality and mental health domains, there was significant improvement for both groups at the moment effect (pre, 10 and 20 sessions) $(p<0.001)$ and in the mental health item, there was also a significant difference in the interaction effect $(p=0.012)$.

Several studies differ regarding the training protocol with FES associated with several techniques according to the aforementioned studies. With these differences, it becomes difficult to evaluate which protocol would be recommended for lower-limb improvement in the hemiparetic patient.

Table 5. Means and standard deviations: social aspects.

\begin{tabular}{lcccc} 
Group & & Pre & 10 sessions & 20 sessions \\
Control & Mean & 63.90 & 64.60 & 64.60 \\
& $\mathrm{SD}$ & 2.96 & 2.12 & 2.12 \\
& $\mathrm{n}$ & 10 & 10 & 10 \\
\hline \multirow{4}{*}{ Study } & Mean & 66.20 & 66.30 & 66.30 \\
& $\mathrm{SD}$ & 1.03 & 1.16 & 1.16 \\
& $\mathrm{n}$ & 10 & 10 & 10 \\
\hline \multicolumn{5}{c}{ ANOVA Table } \\
Effect & \multicolumn{4}{c}{$0.034^{\star}$} \\
Group (Control X Study) \\
Moment (pre. 10 sessions. 20 sessions) \\
Group x Moment (interaction)
\end{tabular}

SD: standard deviation; *statistically significant. 
This study was important, as in addition to showing the effects of FES, functional kinesiotherapy and associated treatment, it also evaluated the quality of life and activities of daily living of the patient. These variables are significantly impaired in many aspects, especially when the patient is affected by an ischemic CVA in the acute and subacute phases.
In conclusion, functional electrical stimulation associated with functional kinesiotherapy was more effective than functional kinesiotherapy alone, regarding quality of life in the domains (functional capacity and social aspects). Both muscle strength and passive and active range of motion as well as activities of daily living showed no difference between the groups.

\section{References}

1. Sociedade Brasileira de Doenças Cardiovasculares. Primeiro consenso brasileiro do tratamento da fase aguda do acidente vascular cerebral. Arq Neuropsiquiatr 2001;59:972-980.

2. Gagliardi RJ. AVC - Acidente vascular cerebral: 50 FAQ "Frequently asked question”. São Paulo: Editora de Publicações Médicas, 2006.

3. O'Sullivan SB, Schmitz TJ. Fisioterapia: avaliação e tratamento. 4 a ed. São Paulo: Manole, 2004.

4. Daffertshofer M, Mielke O, Pullwitt A, Felsenstein M, Hennerici M. Transient ischemic attacks are more than "ministrokes". Stroke 2004;35:2453-2458.

5. Johnston SC, Gress DR, Browner WS, Sidney S. Short-term prognosis after emergency department diagnosis of TIA.JAMA 2000;284:2901-2906.

6. Meschia JF. Subtyping in ischemic stroke genetic research. J Stroke Cerebrovasc Dis 2002;11:208-219.

7. Hendricks HT, Van Limbeek J, Geurts AC, Zwarts MJ. Motor recovery after stroke: a systematic review of the literature. Arch Phys Med Rehabil 2002;83:1629-1637.

8. Formisano R, Pantano P, Buzzi MG, et al. Late motor recovery is influenced by muscle tone changes after stroke. Arch Phys Med Rehabil 2005;86:308-311.

9. Schaechter JD. Motor rehabilitation and brain plasticity after hemiparetic stroke. Prog Neurobiol 2004;73:61-72.

10. Martins FLM, Guimarães LHCT, Vitorino DFM, Souza LCF. Eficácia da eletroestimulação funcional na amplitude de movimento de dorsiflexão de hemiparéticos. Rev Neurociênc 2004;12:103-109.

11. Soetanto D, Kuo C, Babic D. Stabilization of human standing posture using functional neuromuscular stimulation.J Biomech 2001;34:589-597.

12. Kendall FP, Mccreary EK, Provance PG. Músculos: provas e funções. 4 a ed. São Paulo: Manole, 1995:46.

13. Wrigth PA, Granat MH. Therapeutic effects of functional electrical stimulation on the upper limb of eight children with cerebral palsy. Dev Med Child Neurol 2000;42:724-727.

14. ChaeJ,Yu DA. A critical review of neuromuscular electrical stimulation for treatment of motor dysfunction in hemiplegia. Assist Technol 2000;12:33-49.
15. Powell J, Pandyan AD, Granat M, Cameron M, Stott DJ. Electrical stimulation of wrist extensors in poststroke hemiplegia. Stroke 1999;30:1384-1389

16. Corrêa JCF, Negrão Filho R, Dõcusse Filho AJ, Quialheiro JJA. Tratamento da instabilidade fêmuro-patelar por meio da estimulação elétrica neuromuscular associada à cinesioterapia. Rev Bras Fisioter 1996;1:37-43.

17. Noronha MA, Camargo LC, Minamoto VB, Castro CES, Salvini TF. O efeito da estimulação elétrica neuromuscular (NMES) no músculo tibial anterior do rato. Rev Bras Fisioter 1997;2:71-76.

18. Robinson AJ, Snyder-Macler. Eletrofisiologia clínica: eletroterapia e teste eletrofisiológico. 2a ed. Porto Alegre: Artmed, 2001:109.

19. Brasileiro JS, Villar AFS. Comparação dos torques gerados por estimulação elétrica e contração muscular voluntária no músculo quadríceps femoral. Rev Bras Fisioter 2000;2:75-81.

20. American Physical Therapy Association. Guide to physical therapist practice. Part two: preferred practice patterns neuromuscular. 2nd ed. Phys Ther 2001;81(Suppl 1):S305-S537.

21. Duncan P, Studenski S, Richards L, et al. Randomized clinical trial of therapeutic exercise in subacute stroke. Stroke 2003;34:2173-2180.

22. Dombovy ML, Snadok BA, Basford JR. Rehabilitation for stroke: a review. Stroke 1986;17:363-369.

23. Smith ME, Garraway WM, Smith DL, Akhtar AJ. Therapy impact in functional outcome in a controlled trial of stroke rehabilitation. Arch Phys Med Rehabil 1982;63:21-24.

24. Kesar M, Ding J, Wexler A, Perumal R, Maladen R, Binder-Macleod SA. Predicting muscle forces of individuals with hemiparesis following stroke.J Neuroeng Rehabil 2008;5:7.

25. Carod-Artal J, Egido JA, González JL, Varela de Seijas E. Quality of life among stroke survivors evaluated 1 year after stroke: experience of a stroke unit. Stroke 2000;31:2995-3000.

26. van Straten A, de Haan RJ, Limberg M, van den Bos GA. Clinical meaning of the stroke-adapted sickness impact profile-30 and the sickness impact profile-136. Stroke 2000;31: 2610-2615.

27. Kimberley TJ, Carey JR. Neuromuscular electrical stimulation in stroke rehabilitation. Minn Med 2002;85:34-37. 